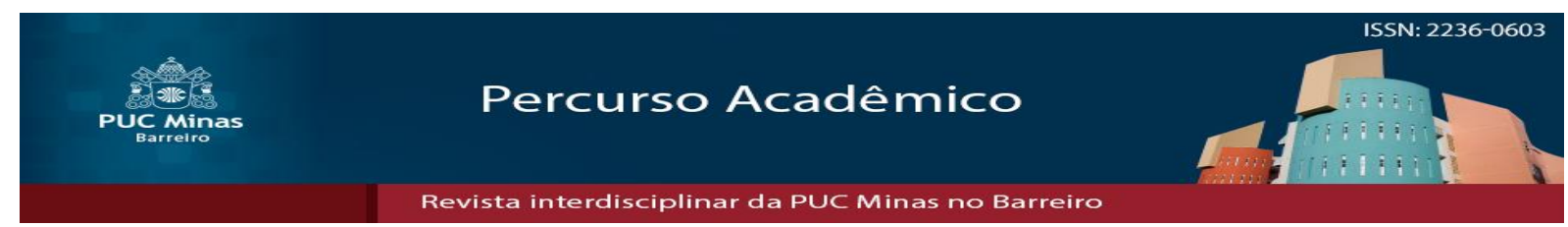

\title{
Study Criteria Established by Consumers and Traders for Pineapple
}

Purchase

\section{Estudo dos critérios utilizados por consumidores e comerciantes em relação à compra de Abacaxi cv. Pérola}

\author{
Maitê Costa da Silva ${ }^{1}$ \\ Márcia Regina Pereira Monteiro ${ }^{2}$ \\ Natália de Carvalho Teixeira ${ }^{3}$ \\ Maria Inês de Souza Dantas ${ }^{4}$ \\ Nísia Andrade Villela Dessimoni Pinto ${ }^{5}$
}

\begin{abstract}
The consumption of fruit in natura has been intensified in the last years as a result of changes in the food habits of consumers who attribute to fruit an important nutritional value. For the fruit in natura market, the visual aspect of the fruit is very important. Knowing consumers profile also helps fruit cooperatives and producers to adjust their offer to the specific needs and desires of the public. The objective of this study was to identify the criteria established by different groups of consumers for pineapple purchase using the focus group technique. Four focus group sessions were conducted with a total of 42 participants (5 nutritionists, 12 fruit and vegetable
\end{abstract}

Artigo recebido em 08 de Novembro de 2018 e aprovado em 20 de Março de 2019

1 Doutorado em Ciências da Saúde pela Universidade Federal de Minas Gerais, Professor Adjunto IV da Pontifícia Universidade Católica de Minas Gerais, Brasil, e-mail: maitecsilva@gmail.com

2 Doutorado em Ciência e Tecnologia de Alimentos pela Universidade Federal de Viçosa, Professor Associado da Universidade Federal de Minas Gerais , Brasil, e-mail: mregina0@ hotmail.com

3. Doutorado e Mestrado em Ciência de Alimentos pela UFMG, Graduada pela Universidade Federal de Minas Gerais, Coordenadora do curso de Nutrição da Faculdade Kennedy, Brasil, e-mail: nacartei@yahoo.com.br

${ }^{4}$ Doutorado em Ciência e Tecnologia de Alimentos na Universidade Federal de Viçosa, Mestrado em Ciência e Tecnologia de Alimentos pela Universidade Federal de Viçosa, Graduação em Nutrição pela Universidade Federal de Viçosa, Técnica de nível superior no Departamento de Nutrição e Saúde da Universidade Federal de Viçosa, Brasil, e-mail: msdantas@ufv.br

${ }^{5}$ Doutorado em Ciências dos Alimentos Universidade Federal de Lavras, Mestrado em Ciências dos Alimentos na Universidade Federal de Lavras, atua no Departamento de Nutrição da Faculdade de Ciências da Saúde na Universidade Federal dos Vales do Jequitinhonha E Mucuri, Brasil, e-mail: nisiavillela@yahoo.com.br 
wholesalers and retailers, 11 undergraduate students and 14 housewives). Appearance ranked first as the criterion chosen by consumers for pineapple purchase, with color $(88 \%)$, shape $(71,5 \%)$, size $(57 \%)$, texture $(54,8 \%)$ and aroma $(50 \%)$ following as the most cited. Wholesalers and retailers presented different criteria such as skin (called a shell), weight, place of origin and fruit characteristics at the moment of purchase. The preference places of the consumers for the purchase of pineapple were: the fruit market (40\%) followed by the supermarket $(38 \%)$ and the central market of the city of Belo Horizonte-MG (5\%).

Key-words: Pineapples. Consumers. Purchase. Focus Group

\section{Resumo}

O consumo de frutas in natura vem se intensificando nos últimos anos. Isso se deve à mudança no hábito alimentar da população, que atribui às frutas um valor nutricional importante. Para o mercado in natura, o aspecto visual da fruta apresenta grande importância. Conhecer o perfil do consumidor é fundamental para que o produtor, as cooperativas, e os distribuidores possam adequar sua oferta às necessidades e desejos específicos do público. O objetivo deste estudo foi identificar os critérios estabelecidos por diferentes grupos de consumidores para a compra de abacaxi utilizando a técnica de grupo focal. Quatro sessões de grupo focal - com 5 nutricionistas, 12 atacadistas e varejistas de hortifrutigranjeiros, 11 estudantes e 14 donas de casa foram conduzidas, totalizando 42 participantes. O principal critério de compra de abacaxi para o consumidor foi a aparência, sendo os itens mais relevantes a cor $(88 \%)$, o formato $(71,5 \%)$, o tamanho $(57 \%)$, a textura $(54,8 \%)$ e o aroma $(50 \%)$. Os atacadistas e varejistas apresentaram critérios diferentes dos demais consumidores entrevistados considerando a malha do fruto, o peso do abacaxi e a região de produção, como características importantes no momento da compra. Os locais de preferência dos consumidores para a compra do abacaxi foram: o sacolação (40\%) seguido do supermercado (38\%) e mercado central do município de Belo Horizonte- MG (5\%).

Palavras- Chaves: Abacaxi. Consumidores. Compra. Grupo Focal. 


\section{Introduction}

Brazil stands out in the world production of pineapple and presented a production in the year 2015 of 1.67 billion fruits (IBGE, 2015).

Pineapples are classified as a non-climacteric fruit, that is means, they only ripe when connected to the plant. They do not undergo any sensorial and nutritional quality alteration after harvest although texture can change (soften) and they can lose their green color (ANTONIOLLI, 2004). Fruit must be harvested at different stages of maturation, depending on destination and distance to the consuming market. Harvest of green fruit must be avoided, as satisfactory quality for consumption will not be reached, especially related to sugar level and less attractive flavor and aroma (REINHARDT et al., 2000).

Pineapples are greatly appreciated for their flavor, but consumers find it difficult to choose them, especially because of their external characteristics. Thus, it is important to survey customers' opinions and and use this information to produce fruit with the characteristics meeting them expectations. Sectors involved with pineapple commercialization must be aware of the marketing trends to identify the attributes having greater value for the final consumer (DELIZA et al., 2003; MIGUEL et al., 2007)

Focus group sessions are an effective way of evaluating the criteria used by consumers to buy products. Focus group technique has been currently used in marketing research, as well as in anthropology, communication, education, marketing, political sciences, psychology, public health, nutrition and food technology research works (WALL, 2001; NETO et al., 2002; BARRIOS \& COSTELL, 2004).

Focus group is a research technique that allows collecting information on a specific subject, based on dialogue and discussion among participants. A group of individuals of the study's target-public answers previously elaborated questions. A moderator, who organizes the discussions and provides a comfortable and adequate environment, leads the sessions. Interaction among participants, sharing and comparing ideas is one of its differentials. This method allows those being interviewed to explain the motivations and reasons for their attitudes and preferences. This makes focus group technique a very useful tool when studying factors affecting food choices and 
consumers' purchase intention. Focus group can also be the link between quality and quantitative studies, since it is used to verify how consumers describe or react to a product (DELIZA et al., 2003; WALL, 2001; BRUG et al, 1995; WAN et al, 2007).

Research on criteria routinely applied by pineapple consumers is important since few works are available in the literature addressing such subject. Knowledge of consumers' opinions and desires allows indirect communication among producers, traders and customers. Consumers can present their idea of the ideal fruit and based on this information, producers and traders can inform and guide on the best way to acquire the product. The objective of this study was to identify the criteria established by different groups of consumers, nutritionists, students, housewives, traders fruit and vegetable wholesalers and retailers, for pineapple purchase using the focus group technique.

\section{Development}

Four focus group sessions were conducted, on different days and locations, each one with a specific group of participants related to the purchase of pineapples. The first group consisted of five nutritionists. The second one was attended by traders fruit and vegetables. The third group consisted of 11 undergraduate students, while the last group was composed by 14 housewives. All focus group sessions were carried out in Belo Horizonte, Minas Gerais, Brazil.

Before each session, the participants answered a questionnaire about demographics and consumption pineapple. The sessions were in the laboratory of dietary technique of the Nutrition Department of the Federal University of Minas Gerais - UFMG had duration of one hour. The participants sat around a rectangular table to allow interaction, eye contact and harmonious discussion. The same moderator led all the sessions. The sessions were also recorded in audio for later transcription and analysis (BRUG et al., 1995).

At the introduction, the moderator defined the focus group's purpose, the moderator's role and the research's objective. Each participant introduced himself/herself to the group to enhance interaction and all were assured that there was no correct or incorrect answer for the questions asked and were encouraged to express their opinions, even if these did not agree with those of the other members of the group. 
The discussion initiated with questions on behavior during purchases and in relation to fruit purchase, more specifically pineapple, following a series of previously elaborated questions (Table 1). Ultimately, a specific question was asked to each group of consumers regarding the use of such criteria in their profession or activity.

Table 1. Questionnaire

Where do you usually buy food? Why?

What time do you usually buy food?

How often do you buy fruit?

How often do you buy pineapple?

Do you associate pineapple size with taste? Which size do you find ideal?

Do you associate pineapple shape with taste? Which shape do you find ideal?

When buying pineapple, which pineapple color do you prefer?

Which color do you find ideal?

Which texture do you find ideal? Do you associate pineapple texture with taste?

Does the aroma influence you when buying pineapple? How? Do you have a favorite pineapple variety?

When buying pineapple, do you look for bruises in the fruit?

\section{Source: Data of the author}

The pineapple variety "Pearl" displaying different degrees of maturation was 
used in all the sessions. Such variety was chosen based on its leading position in the Brazilian market (GONÇALVES et al., 2000). Table 2 presents its classification based on the external color of the fruit and Figure 1 presents the color scale for pineapples.

Table 2- Pineapple classification according to external fruit color.

\section{Maturation Degree Description}

Green

Completely green shell

Other

Up to $25 \%$ of the fruit with green shell

Mixed Color

Up to $50 \%$ of the fruit with yellow-orange shell

Yellow

Over $50 \%$ of the fruit with yellow shell

Source: BRASIL, 2002.

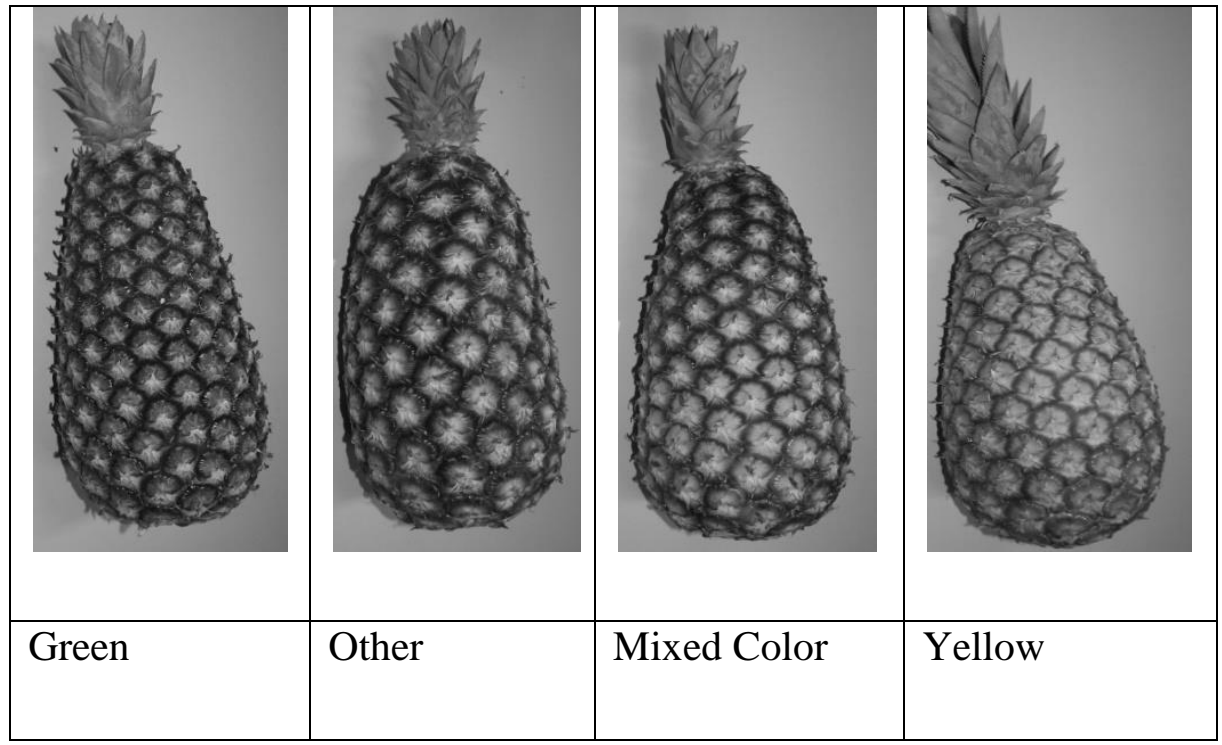

Figure 1. Color scale for pineapples used in this study. 
The data were analysed qualitatively by content analysis and evaluation of the common topics discussed by the groups according to STEWART \& SHAMDASANI (1990). Topics mentioned at least in two groups were considered important. Words and its meanings, contextual meaning, internal consistency, frequency and extension of the comments, answer specifications, and main ideas were taken into account (BRUG et al., 1995).

Table 3. Participants' demographic data $(n=42)$

DEMOGRAPHIC VARIABLES

Age

$20-29$

$30-39$

$40-49$

$50-59$

$60-69$

$>70$

Gender

Male

Female

Family income (minimum wage)

$1-2$

$4-5$
$\%$

38.1

9.5

16.6

7.2

19.1

9.5

29

71

4,8

21.4 


\section{$>5$}

Not available

Instruction

Elementary

High school

Incomplete high school

Incomplete college education

College graduate

Not available
71.4

2.4

7.1

4.8

\section{Source: Data of the author}

The demographic data of the Focus group participants are shown in Table 3. The predominant age range of the interviewed population was $20-29$ years $(38.1 \%)$, with the majority being female. In relation to degree of instruction $38.1 \%$ had incomplete college education. A considerable number of the participants $(71 \%)$ said their family income was above 5 minimum wages and only $4.8 \%$ stated to have family income between 1 and 2 minimum wages.

The majority of the interviewed consumers $(97.7 \%)$ said they usually consume fruit, and $62 \%$ said that they consumed it daily. Pineapples, bananas, apples, oranges, papayas, and grapes were the six fruits preferred by the consumers. Regarding pineapple consumption frequency, most of those interviewed (52.4\%) stated that they consumed it weekly, $16.7 \%$, monthly and $14.3 \%$, daily. The form of pineapple consumption most cited was fruit in natura followed by juice and pie.

For $40 \%$ of the consumers, fruit market was the establishment preferred for fruit purchase, followed by the supermarket (38\%) and central market (5\%). Price is important but it is not enough to ensure sale of a fruit product, if that product is of low 
quality and sold at unclean places. Consumers clearly showed to prefer the following attributes, when choosing a purchase place: practicality, quality, variety, location and product freshness (Figure 2). GONÇALVES (1998) observed that quality and price were the most relevant items for consumers purchasing fresh fruit in Lavras-MG.

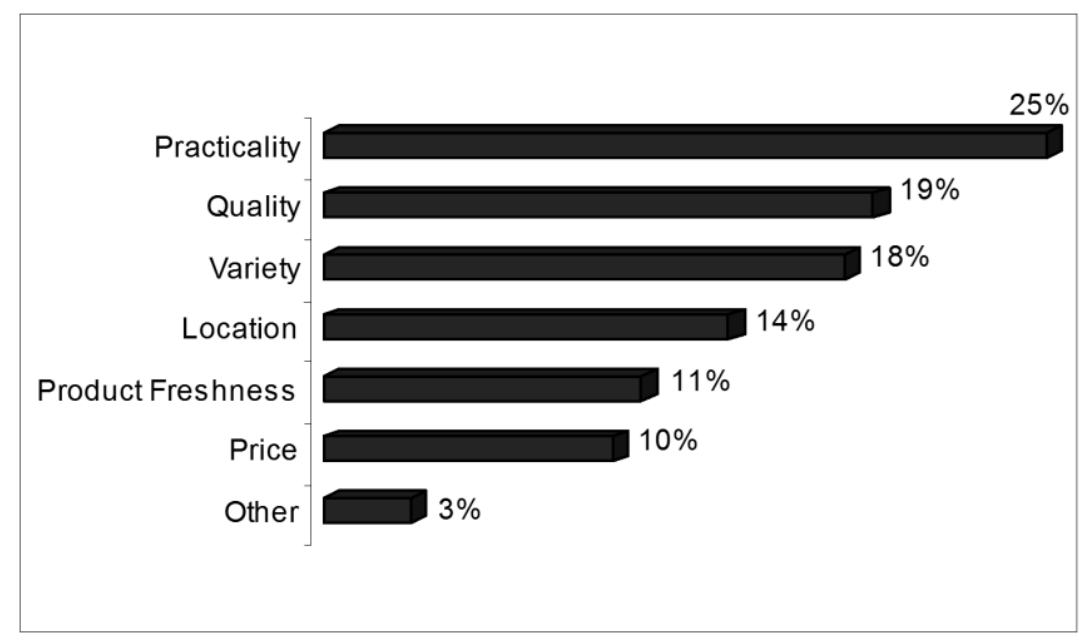

Figure 2. Important attributes to choose purchase place.

Thirty percent of those interviewed said they preferred to purchase fruit in the morning. Thirty eight percent said they buy pineapple every week and $28 \%$ every two weeks (Figure 3).

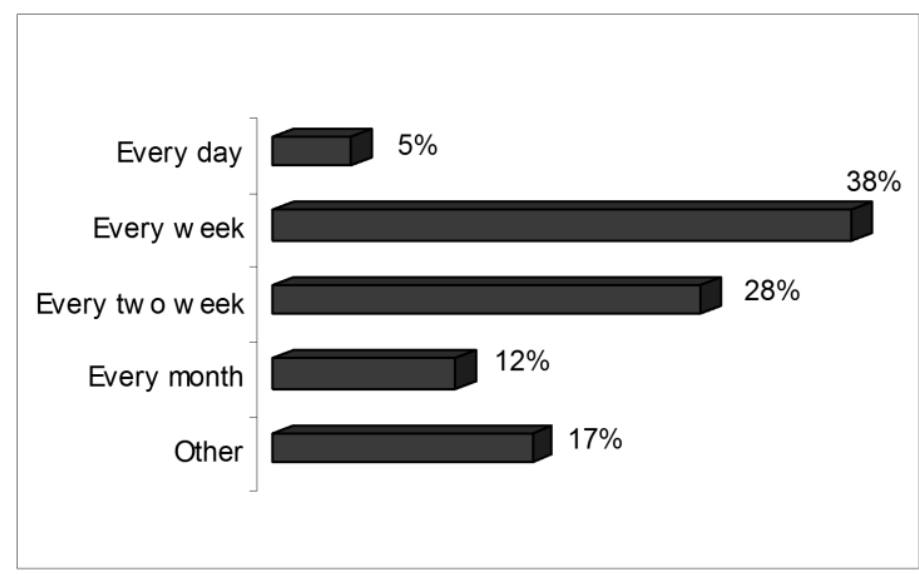

Figure 3. Frequency of Pineapple Purchase. 
The main criterion considered for pineapple purchase was fruit appearance. Consumers considered fruit with bruises to ruin faster than those without them.

Many of those interviewed stated that they associate fruit size (57\%) and shape $(71.5 \%)$ with flavor, using this characteristic as purchase criterion. The study found that both the (larger) size and form of the fruit (round) better the aroma and flavor. Regarding aroma, $50 \%$ of the participants said they associated this attribute to flavor, and some consumers commented that when aroma is very strong, they believe the fruit are "overripe". For $54.8 \%$ of the participants, fruit texture was also associated with flavor. In a similar study, GONÇALVES (1998) also found that appearance, texture, flavor, nutritional value and aroma, in this order, were the main attributes of fruit quality to be used as criteria when evaluating fresh fruit purchase.

Color was considered important for $88 \%$ of the participants, being directly associated with fruit sugar level, maturation and freshness. Mixed color (yellow-orange) and yellow were the preferred colors for $47.6 \%$ and $23.8 \%$ of those interviewed, respectively. DANTAS et al (2004) confirmed the importance of color when evaluating the intention of purchasing processed fruit, with this attribute being considered one of the most relevant characteristics affecting its acquisition.

In relation to the pineapple varieties, the answers diversified. Most participants in the nutritionist group (80\%) and all wholesalers and retailers opted for the purchase of the "Pearl" variety. However, students and housewives said the pineapple variety does not influence the purchase.

All the participants said that they declined to buy fruit with bruises and black spots.

The answers provided by the wholesalers and retailers differed from those of other consumers for the criteria used to choose fruit. Items besides those cited in the two other groups were mentioned, such as fruit shell, weight, and region. One of the wholesalers said: "We prefer fruit with a clean shell, free of soft spots and bruises and with a large crown. Consumers definitely do not know how to choose pineapple. Contrary to common belief, the ease with which leaves can be pulled out is not necessarily a sure sign of ripeness. The best fruit is $100 \%$ mass, heavy and juicy)". The observations made by traders with years of experience purchasing and selling pineapple do not necessarily reflect consumers' desire since food choice is a complex process, influenced by many factors as observed by GUERRERO et al. (2000) 
It was verified that there is no single criterion for choosing pineapple, with option being influenced by individual experiences, food habit and taboos, as well as food appearance, size, aroma, texture, and color -as also verified by IOP et al. (2006). Purchase decision results from the interaction between knowledge and previous experiences, helping each consumer create his/her own perception of the ideal fruit, in agreement with findings by RAGAERT et al. (2003).

Understanding consumers' needs and behavior is an important factor for market product success. This study showed that focal group is a viable technique to verify the criteria used by consumers to purchase pineapple. DELIZA et al. (2003) made this observation when analysing the attitude of consumers towards labels on pineapple juice packing, using the same technique.

\section{Conclusion}

The main criteria applied for pineapple purchase by consumers in Belo Horizonte/MG was appearance, with size, shape, aroma, texture and color being the most relevant items. The wholesalers and retailers interviewed presented criteria different from those of the other consumers, on account of their wide experience in the subject. For them, fruit shell, weight and region of origin are also important criteria.

Purchase decision is a result of the interaction between knowledge and previous experience, which allows each consumer to create his/her ideal fruit model. The differences verified between the different groups of consumers analysed in this study can be attributed to such experiences.

It was concluded that, despite considerable knowledge dissemination, excessive information can have a negative influence on pineapple purchase decision. Thus, it is important to inform consumers about the best way to acquire food products by promoting fairs, events and media dissemination.

This study confirmed the need to inform and guide consumers on the best way to acquire high quality fruit. Knowing consumers' opinions and doubts, needs and behavior promotes good retail and wholesale market performance and consequently, benefits all the productive chain. 


\section{References}

ANTONIOLLI, L.R. Processamento mínimo de abacaxi 'Pérola', Campinas, 2004. 166f. These (Agricultural Engineering pH.D.) - Food Engineering College, Campinas, State University (UNICAMP).

BARRIOS, E.X.; COSTELL, E. Review: Use of methods of research into consumers' opinions and attitudes in food research. Food Science and Technology International, v. 10, n.6, p. 359-371, 2004.

BRASIL, Ministério da Agricultura, Pecuária e Abastecimento - MAPA. Instrução Normativa $N^{o} 001$ de 01 de Fevereiro de 2002: Regulamento Técnico de Identidade e de Qualidade para a Classificação do Abacaxi In Natura. Available from: <http://www.pr.gov.br/claspar/pdf/abacaxi001_02.pdf> [03/01/2007].

BRUG J.; DEBIE S., VAM, A. P., WEIJTS, W. Psychosocial determinants of fruit and vegetables consumption among adults: results of focus group interviews. Food Quality and Preference, v. 6, p. 99-107, 1995.

DANTAS, M.I.S.; MINIM, V.P.R.; DELIZA, R.; PUSHMANN, R. The effect of packaging on the perception of minimally processed products. Journal of International Food \& Agribusiness Marketing, v. 16, n. 2, p. 71-83, 2004.

DELIZA R., ROSENTHAL, A.; SILVA, A.L.S. Consumer attitude towards information on non conventional technology. Trends on Food Science \& Technology, v. 14, p. 4349, 2003.

GONÇALVES, J.R.A. O consumidor de frutas frescas da cidade de Lavras-MG, 1998. 122f. Dissertação (Mestrado em Administração Rural) - Universidade Federal de Lavras, Lavras, 1998.

GONÇALVES, N.B. Abacaxi. Pós-colheita. Brasília Embrapa Comunicação para Transferência de Tecnologia, 2000, p. 16 -17.

GUERRERO, L.; COLOMEL, Y.; GUÀRDIA, J.; XICOLA, R. Consumer attitude towards store brands. Food Quality and Preference, v. 11, p. 387-395, 2000. 
IBGE, Instituto Brasileiro de Geografia e Estatística. Levantamento sistemático da produção agrícola. Rio de Janeiro: IBGE, 2015a. Disponível: Acesso em: 27 out. 2016. IOP, S.C.F, Teixeira, E.; Deliza, R. Consumers reshearch: extrinsec variables in food studies. British Food Journal, 108(11):894-903, 2006.

MIGUEL, A.C.A.; SPOTOZ, M.H.F.; ABRAHÃO C.; SILVA, P.P.M. Aplicação do método QDF na avaliação do perfil do consumidor de abacaxi "pérola". Ciência e Agrotecnologia, Lavras, v. 31, n.2, p. 563-569, 2007.

NETO, O.C.; MOREIRA, M.R.; SUCENA, L.F.M. Grupos Focais e Pesquisa Social Qualitativa: o debate orientado com técnica de investigação. In: XIII Encontro da Associação Brasileira de Estudos populacionais; 2002, Novembro 04 a 08; Ouro Preto, MG.

RAGAERT, P.; VERBEKE, W.; DEVLIEGHERE, F.; DEBEVERE, J. Consumer perception and choice of minimally processed vegetables and packaged fruits. Food Quality and Preference, v. 15, p. 259-270, 2004.

REINHARDT, D.H. et al. Abacaxi. Produção: aspectos técnicos. Brasília: Embrapa Comunicação para Transferência de Tecnologia, Frutas do Brasil, v. 7, p. 13-17, 2000 .

STEWART, D.W.; SHAMDASANI, P.N. Focus groups - theory and practice. Newbury Park , California : Sage Publication, 1990.

WALL, A.L. Evaluating an undergraduate unit using focus group. Quality Assurance in Education, v.9, n.1, p.23-31, 2001.

WAN, V.C.H.; LEE, C.M, LEE, S.Y. Understanding consumer attitudes in edible films and coatings: focus group findings. Journal of Sensory Studies, v.22, p. 353-366, 2007. 